\title{
Sustainable Land Management Using Spatial Analyst in North Nile Delta Soil, Egypt
}

\author{
F.S. Moghanm ${ }^{1}$, A.Y. Darwish ${ }^{1 *}$, Ekhlas M. Elwakel ${ }^{1}$, M.I. El Shahawy ${ }^{3}$ A. \\ Shalaby ${ }^{2}$ \\ ${ }^{1}$ Soil and Water Department, Faculty of Agriculture, Kafrelsheikh University, 33516, \\ ${ }^{2}$ National Authority for Remote Sensing and Space Sciences, Cairo 1564 Egypt \\ ${ }^{3}$ Soil, Water and Environment Institute, Agriculture Research Center, Kafr El-Sheikh, \\ Egypt.
}

\begin{abstract}
USTAINABLE land management (SLM) in agriculture is a complex topic that incorporates $\checkmark$ many features, including biophysical, socioeconomic and environmental factors. To integrate land productivity, security, protection, economic viability and social acceptability indices, spatial analysis (ordinary Kriging) functions in a geographic information system (GIS) were employed to estimate the sustainability index. A SLM model was designed in ArcGIS to evaluate SLM, promote production services (productivity), reduce production risks (security), reduce the pressure on natural resources and protects soil and water degradation (protection). The model was designed to be economically viable (feasibility) and to be acceptable (susceptibility). This study aimed to evaluate sustainable agricultural land in Desouk district, north Nile Delta, Egypt, through a combination of five indices. The sustainability index data indicate that the area can be classified into three classes i.e., low and high class II areas above the threshold of sustainability and class III areas below the threshold of sustainability, representing $64 \%, 34 \%$ and $2 \%$ of the investigated area, respectively. It was found that most of the agricultural land in the study area tends to be marginally higher than the threshold for sustainability.
\end{abstract}

Keywords: GIS, Remote sensing, Soil, Sustainable land management.

\section{Introduction}

Sustainability indicators have proliferated as sustainability assessments have become increasingly common. As a result, there are now a wide range of sustainability assessment approaches, including indicators, product-related assessments and integrated assessment tools (Ness et al., 2007). Sustainable agricultural systems aim to develop new farming practices that are also safe and do not degrade the environment (Lichtfouse et al., 2009). Sustainable agriculture refers to practices that meet current and future societal needs for food and feed, ecosystem services and human health and that maximize the net benefits for people, without compromising the ability of future generations to meet their own needs by improving natural resources (Tilman et al., 2002). However, agricultural sustainable land management (SLM) is necessary to shorten the gap between planning practices and research regarding landscapes
(Antonson, 2009). Crop yield is widely used as a sustainability indicator - this parameter not only quantifies production in terms of land area over time but also allows for the identification of gaps between experimental yield and farmer yield (ElNahry, 2001 and Moghanm, 2015).

Biophysical elements (productivity, security and protection) and socio-economic aspects (economic viability and social acceptability) are used in Egypt to combat sustainability constraints that hinder agricultural development and to reduce these constraints to acceptable levels for mass production endeavors (Abdel Kawy \& Darwish, 2014; Nawar, 2009; El Bastawesy et al., 2013 and Ali \& Shalaby, 2013). As SLM becomes more important than land supply for development, it is important to determine whether current land management in Egypt is in the process of becoming more or less sustainable. Farmers, researchers and policy makers have become interested in 
integrative measures of the current status of land quality and its changes over time (Hurni, 2000). There is a growing consensus that the long-term sustainability of agriculture and rural communities can be enhanced through locally based planning and management at the farm scale, including the farm recommendation unit and resource management (Eswaran et al., 2000).

The current study aimed to evaluate the sustainability of agricultural land in Desouk district, Kafr El-Sheikh governorate of the north Nile Delta, Egypt, through a combination of soil productivity, security, protection, economic viability and social acceptability indices.

\section{Materials and Methods}

\section{Study area}

The study area (Fig. 1) is located in the northwestern part of the Nile Delta in Egypt $\left(31^{\circ} 00^{\prime} 36.9^{\prime \prime}-31^{\circ} 17^{\prime} 3.4^{\prime \prime} \mathrm{N}, 30^{\circ} 48^{\prime} 49.7^{\prime \prime}-\right.$ $\left.30^{\circ} 35^{\prime} 39.5^{\prime \prime} \mathrm{E}\right)$ with an area of approximately $319.5 \mathrm{~km}^{2}$. Elevation of the study area ranged (3-5 meter). It has an arid climate, with annual rainfall of approximately $167 \mathrm{~mm} /$ year that falls mainly between October and March, and air temperatures of $12-23.4^{\circ} \mathrm{C}$ in winter and $26-45^{\circ} \mathrm{C}$ in summer. The mean evaporation reaches its maximum in August, at $7 \mathrm{~mm} /$ day. When the temperature is comparatively low, the minimum values are observed in January and December, and the highest value is recorded between June and September (Climatological Normal for Egypt, 2011).

\section{Soil sampling and laboratory analysis}

The locations of soil profiles were selected according to landforms and physiographic map units. A total of 21 soil profiles were collected in the studied soils of the Desouk region to represent the different preliminary mapping units (Fig. 1). Water samples were collected from irrigation, drainage and the water table from the soil profile locations. Detailed socio-economic data about the studied area were collected through field questionnaires. Land surveys and laboratory analyses were conducted, and socio-economic data were generated. A database of the area was constructed with an attribute table using Arc-GIS 10.1 software. The soil profiles were morphologically described according to the FAO Guidelines for Soil Description (FAO, 2006). The collected soil samples were air dried, crushed and passed through a 2-mm sieve to obtain fine earth for analysis. Electrical conductivity (EC), calcium carbonate content, organic carbon content, $\mathrm{pH}$, cation exchange capacity (CEC), and N, P and $\mathrm{K}$ contents were determined according to the United States Department of Agriculture methods (USDA, 2004).

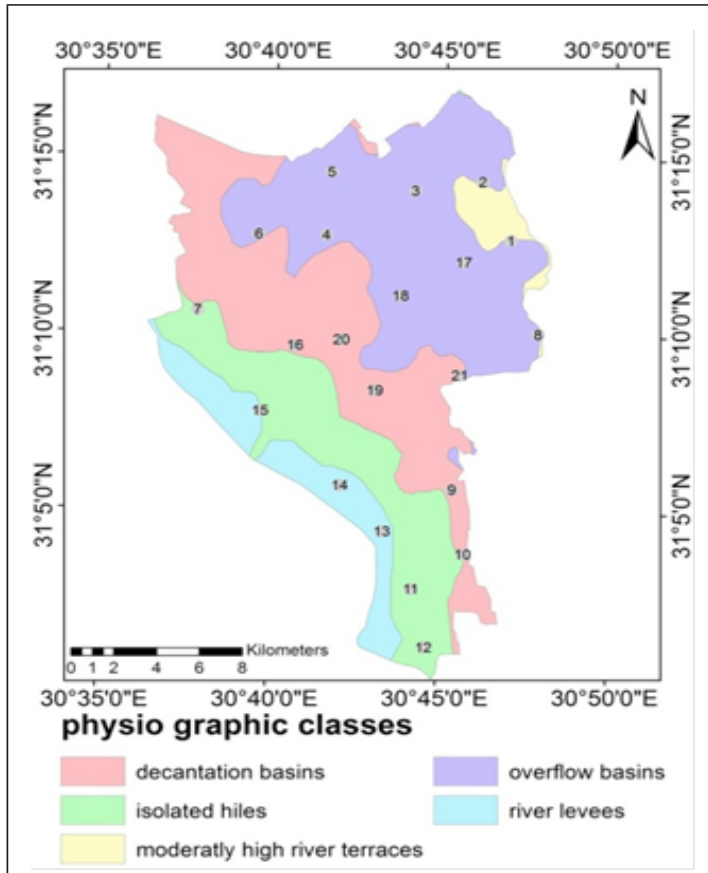

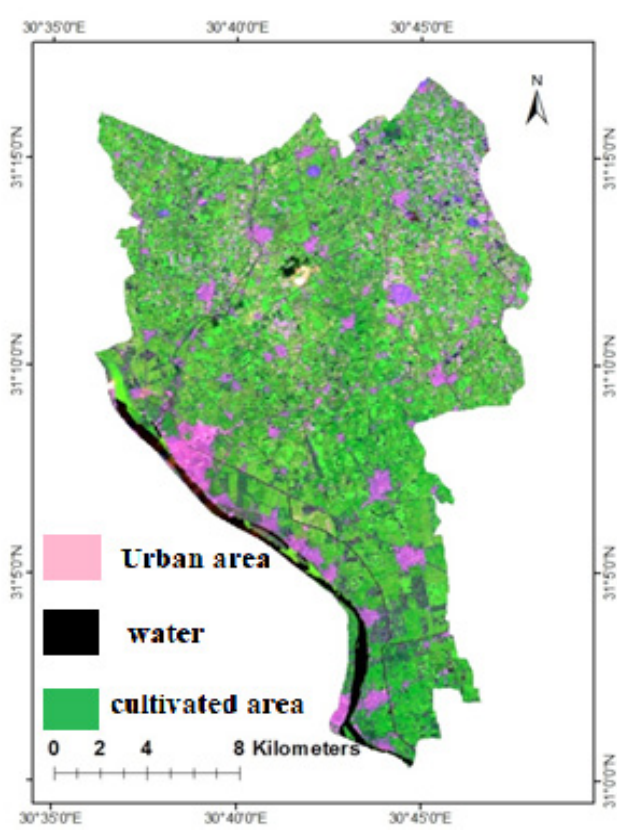

Fig. 1. Physiographic map and $\mathrm{ETM}^{+}$image of the study area.

Egypt. J. Soil. Sci. 58, No. 4 (2018) 


\section{Assessment of SLM}

To determine the condition of soil sustainability, we used the international framework for evaluating sustainable land management (FESLM) established by Smith and Dumanski (1993), as adapted for Egyptian conditions by El-Nahry (2001). The FESLM combines technologies, policies and activities aimed at assimilating socio-economic principles with environmental concerns and that contain the five supports of sustainable land management (productivity, protection, security, economic viability and social acceptability).

To evaluate the current sustainability status in the study area, the current land-use conditions, management practices, environmental factors, and economic and social conditions were recognized. An SLM model was developed using Arc-Map 10.1 software interpolation Inverse distance weighted (IDW) method. Figure 2 explains the input data required, the equations used and the outputs of the designed cartographic model. The model was designed for processing the database of land resource and socioeconomic data that characterize the physiographic map. The final outputs of the model are the productivity, security, protection, economic viability, social acceptability and sustainability indices of the studied area. Every indicator has a scale from 0.0 to 1.0 . The actual values are affected by each other, and the sustainability index ranges between 0.0 and 1.0. The SLM was divided into four classes according to the obtained values of the sustainability index equations. These classes are $\mathrm{C} 1, \mathrm{C} 2, \mathrm{C} 3$ and $\mathrm{C} 4$ for sustainability index value ranges of $1-0.6,0.6-0.3,0.3-0.1$ and $0.1-0$, respectively.

\section{Results and Discussion}

\section{Physiographic map}

The landscape in the study area is a flood plain. The following five main landforms were identified: decantation basins, isolated hills, moderately high river terraces, overflow basins and river levees, which covered $27.9 \%, 22.4 \%$, $26.5 \%, 19.6 \%$ and $3.6 \%$ of the total area, respectively (Fig. 1).

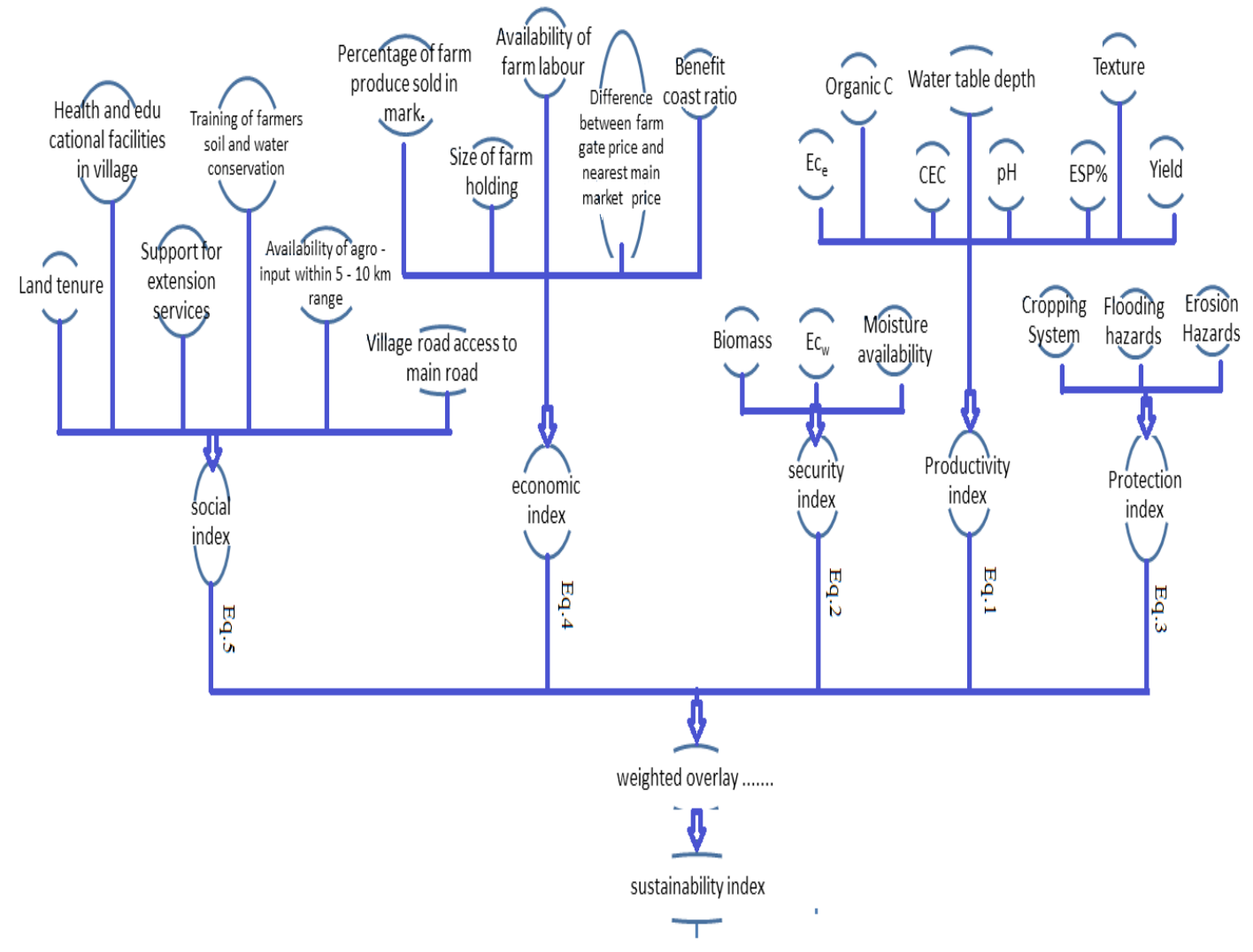

Fig. 2. Schematic diagram of the sustainable land management (SLM) model 


\section{Soil data}

The soil data (Table 1) show that the water table depth ranged from 93 to $152 \mathrm{~cm}$ in all soil profiles. The soil $\mathrm{pH}$ values ranged between 7.95 and 8.64 in the different soils. High values characterize the decantation basins. The soil EC was moderate to high (1.06-13.39 dS/m). Low values represent the soils of isolated hills.

The calcium carbonate and organic carbon contents were low in the studied soils ranging from $0.75 \%-4.5 \%$ and $0.28 \%-1.32 \%$, respectively. The CEC was moderate to high in the soils (31.17$49.12 \mathrm{cmol} / \mathrm{kg}$ soil) but was low in the soils of isolated hills, and a high value characterized the overflow basins. The ESP was low to high and ranged between $2.77 \%$ and $24.06 \%$ with the highest values found in the overflow basins. The ranges of N, P and $\mathrm{K}$ contents were 56-308, 0.332.54 and 7.4-31.76 ppm, respectively. Low $\mathrm{N}$ values were found in the soils of river levees and isolated hills, and the high $\mathrm{M}$ values were found in overflow basins. Low $\mathrm{P}$ values were found in the soils of overflow basins and high $\mathrm{P}$ values were found in river levees. The low $\mathrm{K}$ values were found in the soils of isolated hills, and high $\mathrm{K}$ values were found in river levees.

\section{Determination of agricultural SLM}

Productivity index (A)

Soil productivity refers to the quantity of yield from agricultural processes. The productivity index was calculated using the following equation (El-Nahry, 2001 and Moghanm, 2015):

ProductivityIndex $=\frac{A}{\times} \times \frac{B}{\times} \frac{C}{\times} \times \frac{D}{E} \times \frac{F}{100} \times \frac{G}{10 q}$ Eq $\begin{array}{llllllll}100 & 100 & 100 & 100 & 100 & 100 & 100 & 100\end{array}$

where $\mathrm{A}$ is relative yield $\%, \mathrm{~B}$ is texture, $\mathrm{C}$ is $\%$ organic carbon, $\mathrm{D}$ is soil $\mathrm{pH}, \mathrm{E}$ is $\mathrm{CEC}, \mathrm{F}$ is profile depth, $\mathrm{G}$ is salinity and $\mathrm{H}$ is alkalinity. The results revealed that the security index ranged from 0.77 to 0.90 , as shown in Table 2 and Fig. 4 . The higher index value refers to water quality, which is represented by moisture availability and biomass.

Security (B) and protection indices $(C)$

The security index depends on moisture availability (A), water quality (B) and biomass (C), whereas the protection index depends on erosion hazards by water and winds (A), flooding hazards (B) and cropping system (C) based on the following equations:

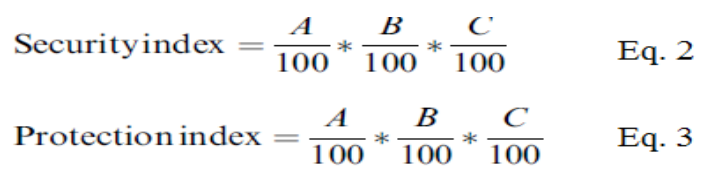

TABLE 1. Chemical analysis of studied soil samples

\begin{tabular}{cccccccccc}
\hline $\begin{array}{c}\text { Profile } \\
\text { No. }\end{array}$ & $\begin{array}{c}\text { Organic } \\
\text { Carbon } \\
\mathbf{( \% )}\end{array}$ & $\begin{array}{c}\mathbf{p H} \\
\mathbf{1 : 2 . 5}\end{array}$ & $\begin{array}{c}\text { CEC (cmol/ } \\
\mathbf{k g} \text { soil) }\end{array}$ & $\begin{array}{c}\text { Nutrient availability } \\
\mathbf{( p p m )}\end{array}$ & $\mathbf{N}$ & $\mathbf{P}$ & $\begin{array}{c}\text { Water table } \\
\text { /profile }\end{array}$ & $\begin{array}{c}\text { EC } \\
\text { (depth } \mathbf{( c m})\end{array}$ & $\begin{array}{c}\text { ESP } \\
\mathbf{( \% )}\end{array}$ \\
\hline 1 & 0.54 & 7.97 & 49.12 & 168 & 0.5 & 14.16 & 105 & 13.39 & 9.24 \\
2 & 0.65 & 8.16 & 36.07 & 168 & 0.69 & 26.28 & 110 & 11.20 & 5.34 \\
3 & 0.97 & 8.21 & 39.36 & 168 & 0.75 & 18.54 & 102 & 5.00 & 8.07 \\
4 & 0.74 & 8.49 & 44.98 & 84 & 0.33 & 14.24 & 140 & 3.41 & 9.47 \\
5 & 0.86 & 8.27 & 34.50 & 112 & 0.66 & 22.26 & 112 & 5.31 & 11.81 \\
6 & 0.87 & 8.41 & 37.75 & 252 & 2.1 & 17.5 & 99 & 3.46 & 9.53 \\
7 & 0.52 & 8.51 & 44.26 & 168 & 0.91 & 13.8 & 155 & 1.85 & 5.44 \\
8 & 0.67 & 8.33 & 34.99 & 196 & 2.38 & 20.44 & 94 & 3.02 & 6.72 \\
9 & 0.48 & 8.43 & 34.63 & 112 & 0.86 & 19.38 & 150 & 2.00 & 6.22 \\
10 & 0.43 & 8.27 & 37.31 & 168 & 2.54 & 14.62 & 130 & 1.275 & 3.36 \\
11 & 0.64 & 8.18 & 31.89 & 224 & 1.35 & 13.9 & 135 & 1.06 & 2.77 \\
12 & 0.51 & 8.45 & 31.17 & 56 & 1.05 & 7.4 & 160 & 1.64 & 4.21 \\
13 & 0.94 & 8.39 & 32.43 & 280 & 1.49 & 22.22 & 93 & 7.02 & 13.51 \\
14 & 1.05 & 8.57 & 35.48 & 56 & 0.72 & 13.98 & 128 & 1.99 & 4.65 \\
15 & 1.32 & 8.54 & 37.88 & 140 & 0.94 & 31.76 & 110 & 1.64 & 5.20 \\
16 & 1.09 & 8.64 & 42.62 & 196 & 0.64 & 18.48 & 140 & 2.50 & 8.72 \\
17 & 1.15 & 7.95 & 44.23 & 308 & 0.44 & 17.98 & 120 & 10.47 & 24.06 \\
18 & 1.03 & 8.24 & 36.46 & 168 & 0.69 & 21 & 144 & 1.13 & 3.22 \\
19 & 0.44 & 8.64 & 35.46 & 140 & 0.91 & 20.46 & 145 & 2.89 & 6.92 \\
20 & 0.37 & 8.57 & 41.38 & 196 & 0.91 & 14.58 & 134 & 4.47 & 9.16 \\
\hline
\end{tabular}

Egypt. J. Soil. Sci. 58, No. 4 (2018) 
The security index ranged from 0.77 to 0.90 (Table 2 and Fig. 4), and the higher index value refers to water quality as represented by moisture availability and biomass. The protection index depends on erosion hazards by water, wind, flooding hazards and the cropping system. The protection index was high (0.9) in all studied soils (Table 2 and Fig. 4). The higher index value refers to erosion and flooding hazards, which are expected to be lower in these areas.

\section{Economic viability index (D)}

The economic viability index depends on five factors for determination of economic viability: the benefit-cost ratio (A), difference between farm gate price and the nearest main market price (B), availability of farm labor (C), size of farm holding (D) and percentage of farm produce, as shown in the following equation:

Economicindex $=\frac{A}{100} * \frac{B}{100} * \frac{C}{100} * \frac{D}{100} * \frac{E}{100} \quad$ Eq. 4

The results obtained show that the economic viability index ranged from 0.72 to 0.90 (Fig. 4 and Table 2).

\section{Social acceptability (E)}

The social acceptability index considers the following six factors: land tenure (A), support for extension services (B), health and educational facilities in the area $(\mathrm{C})$, the training of farmers on soil and water conservation (D), the availability of agro-inputs within a $5-10 \mathrm{~km}$ range (E) and village road access to main roads $(\mathrm{F})$.

$$
\text { Socialindex }=\frac{A}{100} * \frac{B}{100} * \frac{C}{100} * \frac{D}{100} * \frac{E}{100} * \frac{F}{100} \quad \text { Eq. } 5
$$

The social acceptability was 0.9 in all studied soils, and the high index values were the result of increased social services provided to citizens and high-income individuals.

\section{Sustainability index}

The sustainability index was evaluated through the following equation:

Sustainability Index $=\mathrm{A} \times \mathrm{B} \times \mathrm{C} \times \mathrm{D} \times \mathrm{E} \quad$ Eq. 6

Where: $\mathrm{A}$ is the productivity index, $\mathrm{B}$ is the security index, $\mathrm{C}$ is the protection index, $\mathrm{D}$ is the economic index and $\mathrm{E}$ is the social acceptability index (Fig. 5 and Table 2).

TABLE 2. Values of the five sustainability indices for the studied area

\begin{tabular}{cccccccc}
\hline Profile & Productivity & Security & Protection & Economic & Social acceptability & Sustainability & Class \\
\hline 1 & 0.62 & 0.81 & 0.9 & 0.81 & 0.9 & 0.33 & $\mathrm{C} 2$ \\
2 & 0.58 & 0.81 & 0.9 & 0.81 & 0.9 & 0.31 & $\mathrm{C} 2$ \\
3 & 0.69 & 0.77 & 0.9 & 0.81 & 0.9 & 0.35 & $\mathrm{C} 2$ \\
4 & 0.81 & 0.81 & 0.9 & 0.81 & 0.9 & 0.43 & $\mathrm{C} 1$ \\
5 & 0.69 & 0.77 & 0.9 & 0.81 & 0.9 & 0.35 & $\mathrm{C} 2$ \\
6 & 0.77 & 0.77 & 0.9 & 0.81 & 0.9 & 0.39 & $\mathrm{C} 2$ \\
7 & 0.86 & 0.81 & 0.9 & 0.9 & 0.9 & 0.51 & $\mathrm{C} 1$ \\
8 & 0.77 & 0.81 & 0.9 & 0.81 & 0.9 & 0.41 & $\mathrm{C} 1$ \\
9 & 0.77 & 0.9 & 0.9 & 0.72 & 0.9 & 0.40 & $\mathrm{C} 1$ \\
10 & 0.86 & 0.9 & 0.9 & 0.72 & 0.9 & 0.45 & $\mathrm{C} 1$ \\
11 & 0.9 & 0.9 & 0.9 & 0.72 & 0.9 & 0.47 & $\mathrm{C} 1$ \\
12 & 0.9 & 0.86 & 0.9 & 0.72 & 0.9 & 0.45 & $\mathrm{C} 1$ \\
13 & 0.66 & 0.86 & 0.9 & 0.72 & 0.9 & 0.33 & $\mathrm{C} 2$ \\
14 & 0.9 & 0.9 & 0.9 & 0.8 & 0.9 & 0.52 & $\mathrm{C} 1$ \\
15 & 0.9 & 0.9 & 0.9 & 0.8 & 0.9 & 0.52 & $\mathrm{C} 1$ \\
16 & 0.81 & 0.86 & 0.9 & 0.9 & 0.9 & 0.51 & $\mathrm{C} 1$ \\
17 & 0.65 & 0.81 & 0.9 & 0.81 & 0.9 & 0.35 & $\mathrm{C} 2$ \\
18 & 0.95 & 0.77 & 0.9 & 0.81 & 0.9 & 0.48 & $\mathrm{C} 1$ \\
19 & 0.73 & 0.81 & 0.9 & 0.81 & 0.9 & 0.39 & $\mathrm{C} 2$ \\
20 & 0.66 & 0.81 & 0.9 & 0.81 & 0.9 & $\mathrm{C} 2$ \\
21 & 0.73 & 0.9 & 0.9 & 0.81 & & $\mathrm{C} 1$ \\
\hline & & & & & 0.93 & \\
\hline
\end{tabular}

The locations of the profiles within the study area are shown in Fig. 1. 

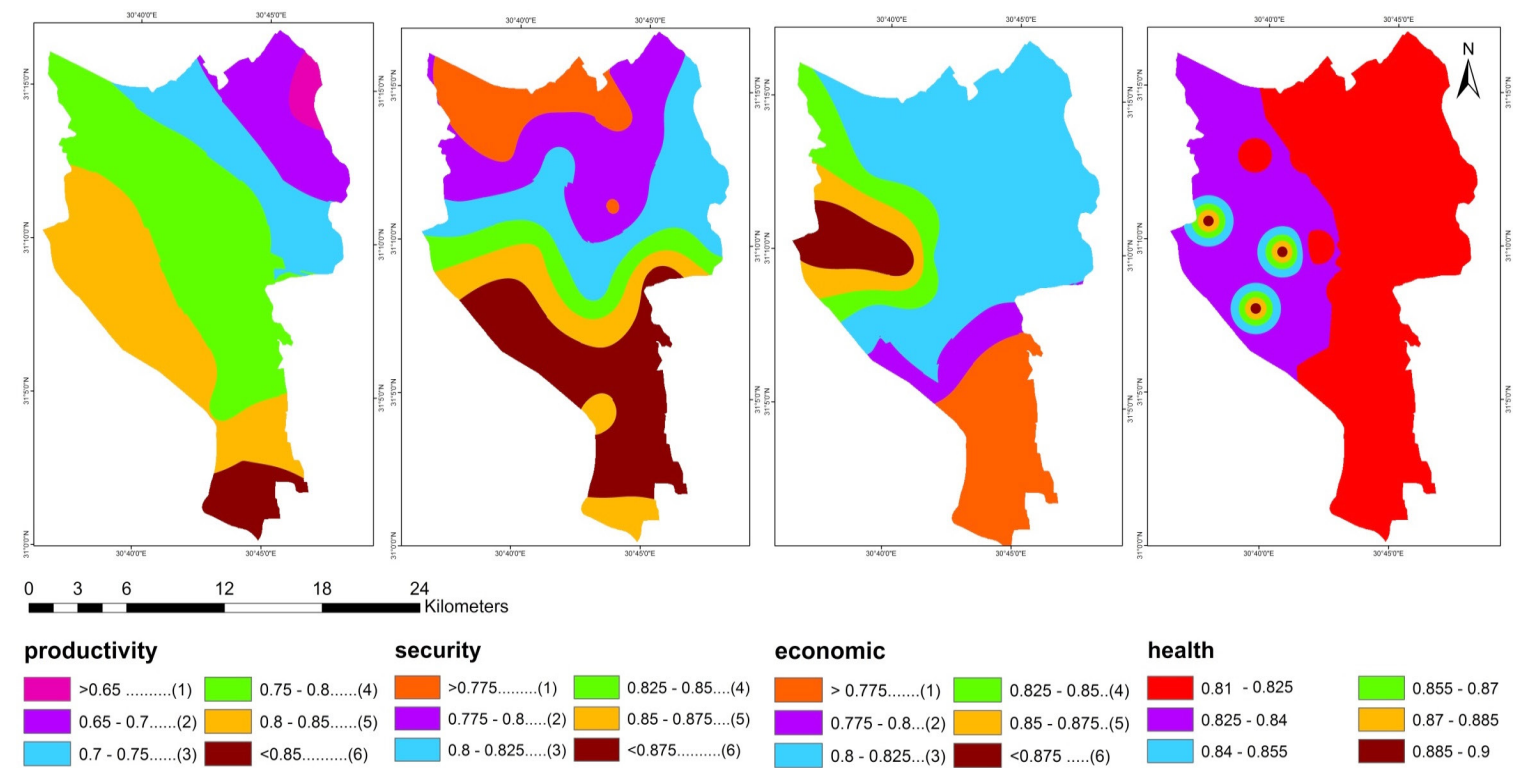

economic

health
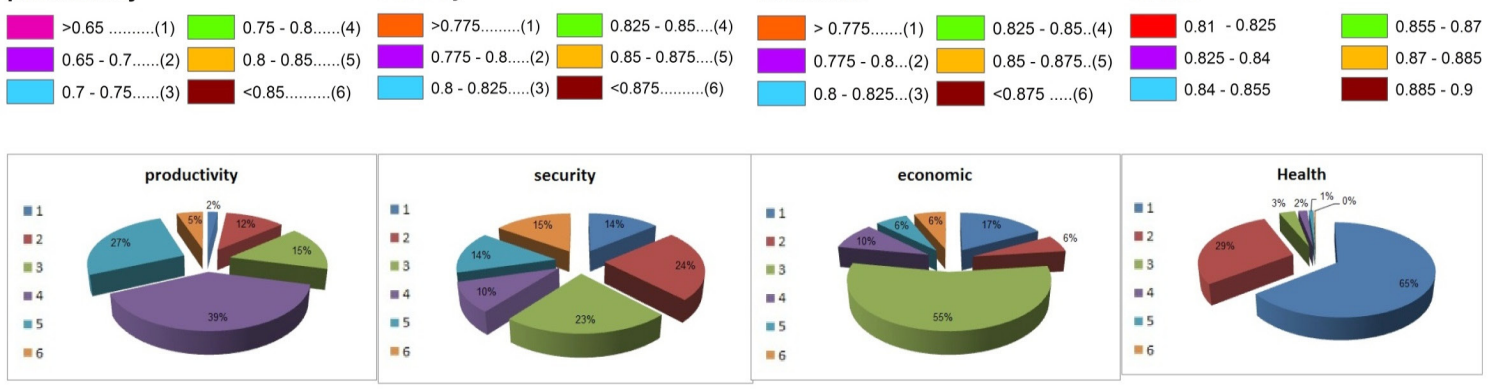

Fig. 4. Spatial distribution of sustainability indices in the study area.

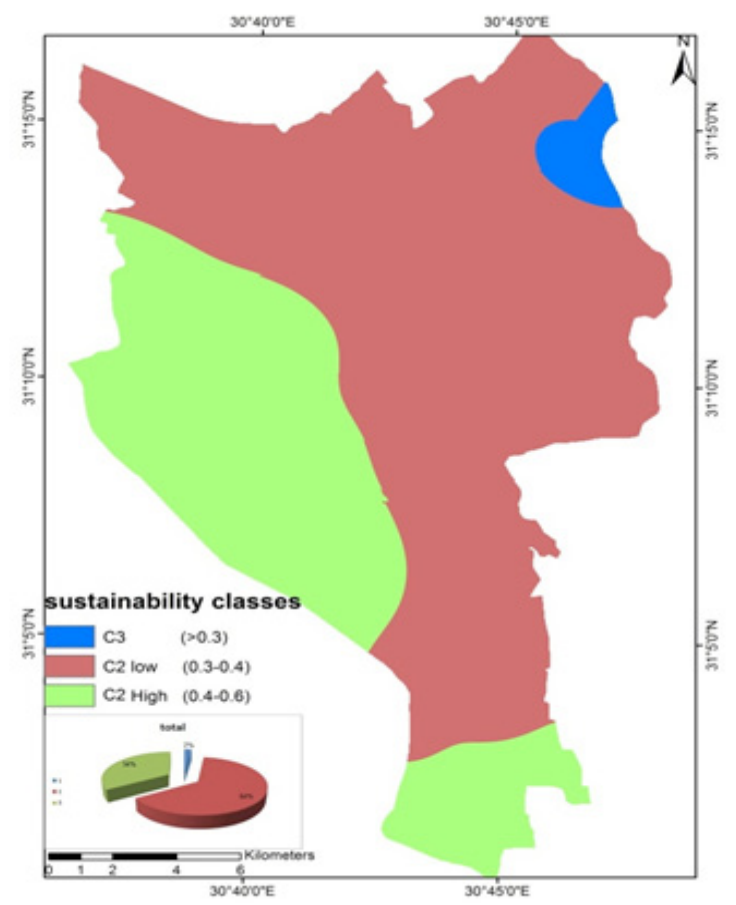

Fig. 5. Spatial distribution of sustainability classes in the study area

Egypt. J. Soil. Sci. 58, No. 4 (2018) 
Productivity: The values of many factors changed dramatically between profiles, especially those of the salinity, relative yield, organic carbon and $\mathrm{pH}$ of the soil. Productivity is the factor most affecting the value of sustainability in the region under study. The main factor affecting on productivity factor of the study area is proximity or distance from Rashid branch, the evidence of productivity index increases west of study area and less as we turn east.

Security: The differences between security index values of different profiles were smaller than those of the productivity index values, and water availability and quality were the main factors influencing security values.

Protection: There were no large differences in the elements of the protection index (water and wind erosion hazards, flooding hazards and cropping system) and thus all the values of the protection index were 0.9 in all studied areas.

Economic criteria were based from a questionnaire circulated among farmers at the study sites and the proximity and distance from the main city were found to be the main factors for economic viability in the region under study.

The most influential factor in the productivity is the proximity of the region or beyond to the main city (Desouq city) where the types of the crops in the nearby areas is dependent on direct marketing projects with higher returns.

\section{Conclusion}

This paper shows that the use of geographical information system extension spatial and statistical analyst, to create high resolution soil maps and models of land capacity, for sustainability is an effective tool to support decision-making in the study area. This method is effective and can be used continuously for its dynamic and ability modification data. The model has proved to be a sensitive way to assess sustainability, as it has the potential to show differences in sustainability and each of its factors across the entire study area, making it an effective tool that can be used by decision-makers to develop strategies that support land sustainability over time. During the statement of changes in the unit of the land under different agricultural practices over time. This paper also showed that the study area is mostly in the first rank of the categories of sustainability, where the ranks of the first, second and third ratios of $64 \%$ and $34 \%$ and $2 \%$ respectively.

\section{References}

Abdel Kawy, W. and Darwish, Kh. (2014) Sustainable multivariate analysis for land use management in ElSharkiya, Egypt. Arabian Journal of Geosciences, 7, 475-487.

Ali R.R. and Shalaby A. (2013) The Use of Cartographic Modeling for the Assessment of Agricultural Sustainability of Damietta Governorate, Egypt. Journal of Applied Sciences Research, 9(1), 248-257.

Antonson, H. (2009) Bridging the gap between research and planning practice concerning landscape in Swedish infrastructural planning. Land Use Policy, 26 (2), 169177.

Climatological Normal for Egypt (2011) the normal for Kafr El-Sheikh Governorate station, (1960 - 2011), Ministry of civil Aviation: meteorological Authority, Cairo, Egypt.

Smith, A.J. and Dumanski, J. (1993) FESLM: An International Framework for Evaluating Sustainable Land Management. World Soils Report, 73, 74p. (En). ISBN 92-5-103419-2.

El Bastawesy, M., Ramadan Ali, R., Faid, A., El Osta, M. (2013) Assessment of water logging in agricultural mega projects in the closed drainage basins of the Western Desert of Egypt. Hydrol. Earth Syst. Sci. 17, 1493-1501.

El-Nahry, A H. (2001) An approach for sustainable land use studies of some areas in northwest Nile Delta,Egypt. Ph.D. Thesis, Soil Science Dept., Faculty of Agric., Cairo. Uni.

Eswaran, H., Arnold, R.W., Beinroth, F.H. and Reich, P.F. (2000) A global assessment of land quality. In preparation.

Fao (2006) Guidelines for Soil Profile Description, $4^{\text {th }}$ edition. Food and Agriculture Organization of the United Nations, Rome.

Hurni, H. (2000) Environmental Impact Assessment Review. Agric Ecosyst Environ., 81, 83-92.

Lichtfouse, E., Navarrete, M., Debaeke, P., Souche` re, V., Alberola, C. (2009) Sustainable Agriculture. Springer-EDPS, ISBN 978-90-481-2665-1, p. 919.

Moghanm, F.S. (2015) Assessment of Sustainable Agricultural Land Management by Using GIS Techniques in North Delta, Egypt. Egypt. J. Soil Sci. 55 (1).

Nawar S. (2009) Mapping units of some soils of elsalam canal basin using the geographic Information

Egypt. J. Soil. Sci. 58, No. 4 (2018) 
systems (gis).MSc Soil and Water Dep. Suez Canal University.

Ness, B., Urbel-Piirsalu, E., Anderberg, S., \& Olsson, L. (2007) Categorising tools for sustainability assessment. Ecological Economics, 60 (3), 498-508.

Tilman, D., Cassman, K.G., Matson, P.A., Naylor, R., Polasky, S. (2002) Agricultural sustainability and intensive production practices. Nature, 418, 671-677.
USDA. (2004) Soil Survey Laboratory Methods Manual Soil Survey Investigation Report No. 42 Version 4.0.

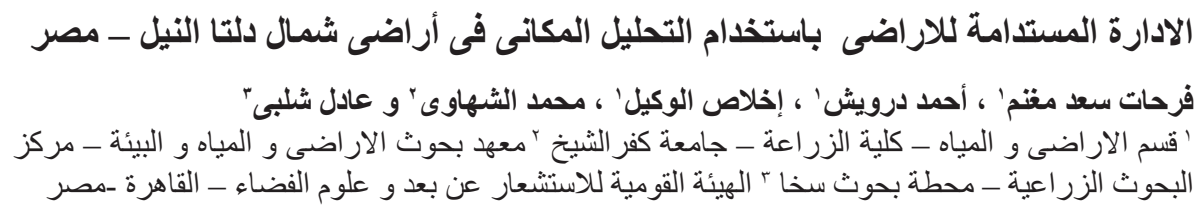

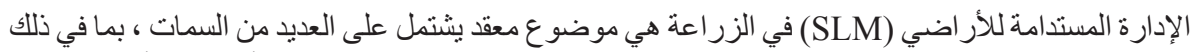

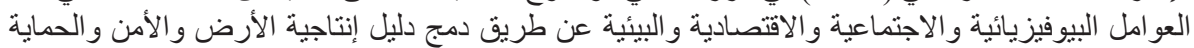

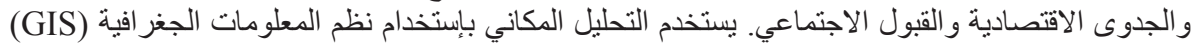

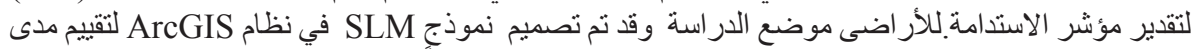

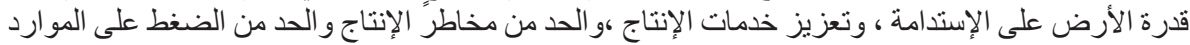

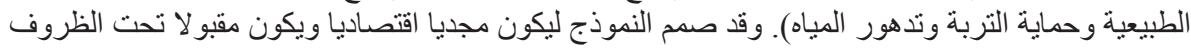

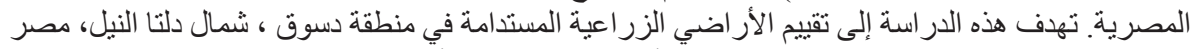

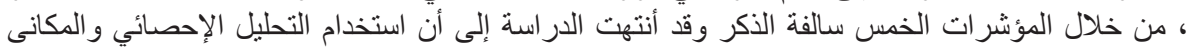

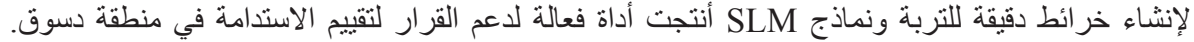

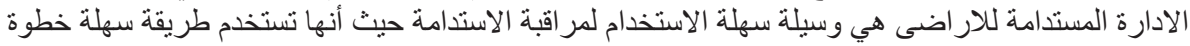

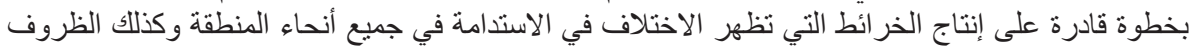

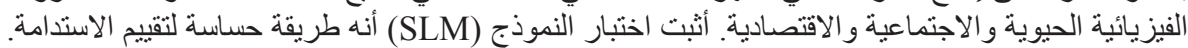

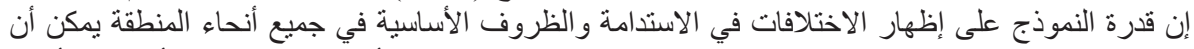

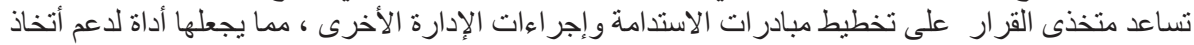

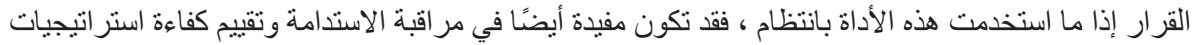

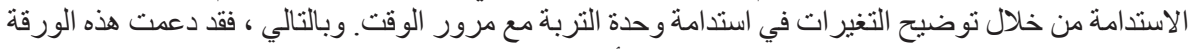

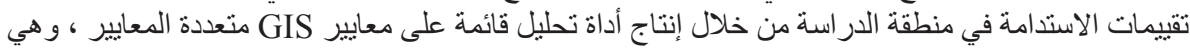

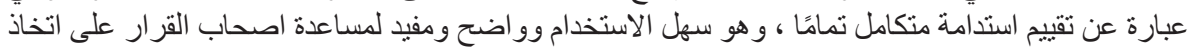

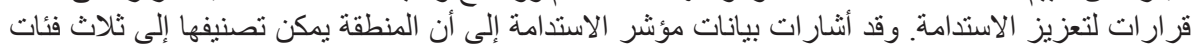

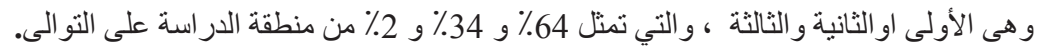

